\title{
PENERAPAN MODEL SCIENCE TECHNOLOGY SOCIETY MELALUI EKSPERIMEN LAPANGAN DAN EKSPERIMEN LABORATORIUM DITINJAU DARI SIKAP PEDULI LINGKUNGAN DAN KREATIVITAS VERBAL SISWA
}

\author{
Ahmad Makmur Santoso ${ }^{1}$, Sajidan $^{2}$, dan Suciati Sudarisman ${ }^{3}$ \\ ${ }^{1}$ Program Studi Pendidikan Sains, Program Pascasarjana, Universitas Sebelas Maret Surakarta \\ Surakarta, 57126, Indonesia \\ smapetanahan@gmail.com \\ ${ }^{2}$ Program Studi Pendidikan Sains, Program Pascasarjana, Universitas Sebelas Maret Surakarta \\ Surakarta, 57126, Indonesia \\ adjids2002@yahoo.com \\ ${ }^{3}$ Program Studi Pendidikan Sains, Program Pascasarjana, Universitas Sebelas Maret Surakarta \\ Surakarta, 57126, Indonesia \\ suciati.sudarisman@yahoo.com
}

\begin{abstract}
ABSTRAK
Penelitian ini bertujuan mengetahui pengaruh pembelajaran model Science Technology Society melalui metode eksperimen lapangan dan laboratorium, antara siswa yang memiliki sikap peduli lingkungan dan kreativitas verbal kategori tinggi dan rendah terhadap prestasi belajar biologi siswa, serta interaksinya. Penelitian ini menggunakan metode true experiment. Populasi penelitian adalah seluruh siswa kelas X SMA Negeri 1 Petanahan Tahun Pelajaran 2012/2013, sebanyak 4 kelas. Sampel penelitian ditentukan secara acak dengan teknik cluster random sampling sebanyak 2 kelas yaitu kelas X4 dan X7. Kelas X4 diberi pembelajaran dengan metode eksperimen lapangan dan kelas X7 dengan metode eksperimen laboratorium. Teknik pengumpulan data menggunakan metode tes untuk mendapatkan data prestasi belajar kognitif, psikomotor dan kreativitas verbal siswa, metode angket untuk mendapatkan data sikap peduli lingkungan, prestasi belajar afektif serta metode observasi untuk memperoleh data afektif, dan psikomotorik. Uji hipotesis penelitian menggunakan anava tiga jalan dengan desain faktorial $2 \times 2 \times 2$. Berdasarkan hasil uji hipotesis data hasil penelitian dapat disimpulkan bahwa: 1) ada pengaruh penggunaan metode eksperimen lapangan dan eksperimen laboratorium terhadap prestasi belajar kognitif, afektif, dan psikomotorik siswa; 2) ada pengaruh sikap peduli lingkungan terhadap prestasi belajar kognitif, afektif, dan psikomotor; 3) ada pengaruh kreativitas verbal terhadap prestasi belajar kognitif, afektif, dan psikomotorik siswa; 4) ada interaksi antara metode dan sikap peduli lingkungan terhadap prestasi belajar kognitif, afektif, dan psikomotorik siswa; 5) tidak ada interaksi antara metode dan kreativitas terhadap prestasi belajar kognitif, afektif, dan psikomotorik siswa, 6) ada interaksi antara sikap peduli lingkungan dengan kreativitas verbal terhadap prestasi belajar kognitif, afektif, dan psikomotor, 7) tidak ada interaksi antara metode, sikap peduli lingkungan, dengan kreativitas verbal terhadap prestasi belajar kognitif, afektif, dan psikomotorik siswa.
\end{abstract}

Kata Kunci: $\quad$ Science Technology Society, Eksperimen Lapangan, Eksperimen Laboratorium, Sikap Peduli Lingkungan, Kreativitas Verbal

\section{Pendahuluan}


ISSN: 2252-7893, Vol 2, No 32013 (hal 204-215)

\section{http://jurnal.fkip.uns.ac.id/index.php/sains}

Pesatnya perkembangan sains dan teknologi telah mempengaruhi kehidupan manusia dalam berbagai bidang. Menyiapkan sumber daya manusia yang berkualitas sedini mungkin sangat dibutuhkan untuk menghadapi tantangan masa depan yang secara kualitatitf cederung meningkat. Berbagai tantangan muncul antara lain menyangkut peningkatan hidup, pemerataan hasil pembangunan, partisipasi masyarakat dan kemampuan untuk mengembangkan sumber daya alam. Hal ini merupakan tantangan yang harus dihadapi institusi pendidikan untuk membekali peserta didik dengan literasi sains untuk menghadapi tuntutan perkembangan sains dan teknologi serta persaingan global.

Depdiknas (2003:2) menyebutkan bahwa sains berkaitan dengan cara mencari tahu tentang alam secara sistematis sehingga sains bukan hanya penguasaan kumpulan pengetahuan yang berupa fakta-fakta, konsepkonsep, atau prinsip-prinsip saja tetapi juga merupakan suatu proses penemuan. Pembelajaran sains diharapkan menjadi wahana bagi para peserta didik untuk mempelajari diri sendiri dan alam sekitar serta prospek pengembangan lebih lanjut dalam penerapannnya di kehidupan sehari-hari.

Berdasarkan Permendiknas No. 22 tahun 2006 tentang standar isi menegaskan bahwa mata pelajaran IPA termasuk biologi yang salah satu karakteristik dalam pembelajarannya memerlukan kegiatan penyelidikan atau eksperimen, sebagai bagian dari kerja ilmiah yang melibatkan keterampilan proses yang dilandasi sikap ilmiah. Adanya kegiatan ini akan menumbuhkan rasa ingin tahu melalui pengalaman langsung yang dilakukan melalui kerja ilmiah (BSNP, 2008). Hal ini menunjukkan biologi mengintergrasikan antara teori dan aplikasi dalam kehidupan nyata sebagai suatu pengetahuan. Dengan demikian pembelajaran biologi merupakan sarana strategis dalam menyiapkan SDM yang akan mampu dan terampil dalam memecahkan permasalahan dalam kehidupannya baik dimasa sekarang ataupun dimasa yang akan datang.

Berdasarkan uraian di atas tersirat perlunya proses pembelajaran IPA (biologi) yang menarik, kontekstual, melibatkan adanya interaksi antara siswa dan pendidik dengan lingkungan sebagai salah satu sumber belajar, sehingga siswa dapat melakukan keterampilan proses sains. Menurut Suciati (2010 : 237) keterampilan proses sains yang perlu dikembangkan diantaranya adalah keterampilan mengamati, mengelompokkan, menafsirkan, meramalkan, mengajukan pertanyaan, berhipotesis, melakukan percobaan, dan mengkomunikasikan hasil percobaan.

Secara umum pembelajaran di Indonesia kenyataan menunjukkan bahwa siswa hanya menghafal konsep dan kurang mampu menggunakan konsep tersebut jika menemui masalah-masalah dalam kehidupan nyata yang berhubungan dengan konsep yang dimiliki. Siswa bahkan kurang mampu menentukan masalah dan merumuskan. Walaupun demikian, disadari bahwa ada juga siswa yang memiliki kemampuan menghafal yang baik serta mampu memahami materi yang dihafal tersebut namun kenyataan mereka sering kurang mampu dalam menggunakan konsep yang telah dihafal tersebut ke dalam suatu situasi yang baru khususnya yang berkitan dengan lingkungan sehari-hari (Trianto, 2010 : 90).

Pembelajaran sains di Indonesia mayoritas masih menggunakan metode pembelajaran yang berpusat pada guru (teacher centered). Pembelajaran sains cenderung terbatas pada transfer ilmu pengetahuan dari guru ke siswa (transfer of knowledge). Pembelajaran sains yang ada belum memberikan kesempatan yag lebih banyak kepada siswa untuk menemukan dan memecahkan sendiri permasalahan yang mereka temukan dalam memahami materi yang dipelajari.

Hasil survei Trends in International Mathematics and Science Study (TIMSS) IPA 2007 rata-rata Indonesia 427 (3.4) menempati urutan ke-35 dari 49 negara dan data Programme of Internastional Student Asessment (PISA) IPA tahun 2006 rata-rata Indonesia 393 (5.7) menempati urutan ke-50 dari 57 negara (Ditjen PMTK, 2007). Kondisi rendahnya literasi IPA siswa-siswa tersebut diprediksi karena kurang terlatihnya kemampuan berfikir siswa-siswa Indonesia pada umumnya. Dalam rangka mengatasi permasalahan tersebut maka solusi yang ditawarkan dengan model STS.

SMA Negeri 1 Petanahan, Kebumen merupakan salah satu sekolah di Kabupaten Kebumen yang termasuk dalam Sekolah Kategori Mandiri (SKM). Akan tetapi prestasi belajar siswa mata pelajaran biologi masih jauh dari harapan. Berdasarkan hasil wawancara 
ISSN: 2252-7893, Vol 2, No 32013 (hal 204-215)

http://jurnal.fkip.uns.ac.id/index.php/sains

siswa dan guru biologi, belum optimalnya hasil belajar biologi siswa diprediksi karena beberapa faktor diantaranya: (1) pembelajaran Biologi di kelas pada kenyataanya masih terpusat pada guru dan guru menggunakan metode ceramah, sehingga pembelajaran cenderung verbal dan transfer pengetahuan juga rendah sehingga kemampuan siswa dalam mengkonstruk dan mengorganisasi konsep pengetahuan masih sangat kurang; (2) proses pembelajaran masih menggunakan metode ceramah dan kurang memberdayakan keaktifan siswa, sehingga minat siswa dalam pembelajaran rendah dan siswa cenderung pasif; (3) pembelajaran Biologi kurang menggunakan lingkungan sebagai sumber belajar sehingga siswa kurang peka terhadap isu/masalah di masyarakat; (4) lokasi sekolah terletak dekat dengan industri kopra dimana limbahnya belum banyak dimanfaatkan; (5) pembelajaran Biologi belum mengkaitkan tekhnologi untuk memecahkan masalah lingkungan terutama masalah limbah rumah tangga dan limbah industri kopra; (6) kemampuan untuk menggunakan keterampilan proses sains siswa rendah terutama dalam melakukan percobaan dan mengkomunikasikan hasil percobaan kepada orang lain; (7) guru kurang menggunakan laboratorium dalam proses pembelajaran sehingga keterampilan proses sains siswa rendah; (8) guru kurang memperhatikan kreativitas siswa yang bervariasi, sehingga hasil belajar kurang optimal; (9) sikap peduli lingkungan siswa juga bervariasi tetapi guru kurang memperhatikan, sehingga prestasi siswa rendah. Menyadari adanya kelemahan-kelemahan dalam pembelajaran biologi di SMA Negeri 1 Petanahan Kabupaten Kebumen, maka perlu solusi untuk memecahkan permasalahan tersebut agar prestasi belajar siswa dapat ditingkatkan dengan memilih model dan pendekatan pembelajaran yang tepat.

Model pembelajaran Science Technology Society (STS) merupakan suatu model pembelajaran yang memadukan pemahaman dan pemanfaatan sains, teknologi dan masyarakat dengan tujuan agar konsep sains dapat diaplikasikan melalui keterampilan yang bermanfaat bagi peserta didik dan masyarakat. Sintak model STS adalah pendahuluan: inisiasi, pembentukan/pengembangan konsep, aplikasi konsep, pemantapan konsep, penilaian. Model STS memiliki beberapa keungulan diantaranya: (1) membentuk individu yang memiliki literasi sains dan teknologi; (2) memiliki kepedulian terhadap masalah masyarakat dan lingkungan; (3) pembelajaran dengan model STS terdapat beberapa metode saintis yang merupakan bagian dari pembelajaran Biologi yaitu melakukan eksperimen untuk mengatasi permasalahan yang ada dilingkungan; (4) mampu mengakomodasi siswa untuk belajar melalui serangkaian kegiatan ilmiah. Hal ini relevan dengan hasil studi Nuray Yoruk et al (2010) menunjukan adanya perbedaan yang signifikan antara kelas kontrol dan kelas perlakuan pada penggunaan model Science Technology Society and Environment (STSE). Perbedaan nyata terlihat pada prestasi kelas kontrol dan kelas perlakuan. Dari hasil postes menunjukan hasil prestasi lebih baik pada kelas perlakuan. Hal ini disebabkan karena pembelajaran dengan STSE mengangkat topik permasalahan yang ada di lingkungan sehingga siswa mudah memahami topik dan konsepkonsep permasalahan. Di samping itu pembelajaran dengan STSE dapat mendorong siswa lebih aktif dan pembelajaran menjadi bersifat student center.

Penerapan model STS akan lebih efektif jika dipadu dengan metode pembelajaran yang tepat seperti eksperimen lapangan dan eksperimen laboratorium. Metode eksperimen lapangan merupakan metode eksperimen yang dilakukan di tempat yang sesungguhnya, baik oleh guru maupun oleh peserta didik. Melalui eksperimen lapangan memungkinkan peserta didik melakukan percobaan dan akan mengobservasi fakta yang terjadi di tempat yang sesungguhnya. Metode eksperimen laboratorium, peserta didik melakukan eksperimen sendiri untuk kemudian diobservasi hasilnya. Metode eksperimen ini dapat dikatakan metode manipulatif, karena peserta didik di pandu untuk mencocokan antara kenyataan dan teori yang di pelajari, pada umumnya menemukan dan memahami konsep melalui pengalamannya sendiri. Eksperimen lapangan dan eksperimen laboratorium dalam STS adalah melakukan percobaan untuk memecahkan permasalahan yang ada di lingkungan dengan memanfaatkan teknologi dan bukan membuktikan atau menemukan suatu konsep tertentu.

Dengan demikian penerapan STS dengan eksperimen lapangan dan eksperimen laboratorium pada materi limbah dan upaya mengatasinya diharapkan dapat meningkatkan 
ISSN: 2252-7893, Vol 2, No 32013 (hal 204-215)

http://jurnal.fkip.uns.ac.id/index.php/sains

prestasi belajar karena siswa dapat mengkonstruk pengetahuannya sendiri sehingga siswa lebih mudah memahami konsep atau materi pelajaran. Melalui pengalaman belajar nyata dan langsung, maka pengetahuan yang diperoleh siswa akan terpatri dalam memori jangka panjang, sehingga menjadi lebih bermakna.

Prestasi belajar dipengaruhi oleh faktor internal dan eksternal yang kuat. Faktor internal siswa seperti: keberagaman sikap peduli lingkungan dan kreativitas verbal yang dimiliki siswa mempengaruhi hasil prestasi belajar siswa.

Berdasarkan hal tersebut dan sekaligus merupakan solusi terhadap permasalahan pembelajaran Biologi di SMA Negeri 1 Petanahan Kabupaten Kebumen maka perlu dilakukan penelitian yang berjudul "Penerapan Model Science Technology Society Melalui Eksperimen Lapangan dan Eksperimen Laboratorium ditinjau dari Sikap Peduli Lingkungan dan Kreativitas Verbal Siswa".

Tujuan dari penelitian ini adalah untuk mengetahui pengaruh model pembelajaran STS, metode eksperimen lapangan, metode eksperimen laboratorium, sikap peduli lingkungan dan kreativitas verbal siswa terhadap prestasi belajar Biologi.

\section{Metode Penelitian}

Penelitian ini dilakukan di SMA Negeri 1 Petanahan dengan alamat Jl. Desa Tresnorejo, Kecamatan Petanahan, Kabupaten Kebumen. Penelitian ini dilaksanakan pada Semester 1 Tahun Pelajaran 2012/2013 pada materi limbah dan upaya mengatasinya.

Metode yang digunakan adalah metode true experiment, yang melibatkan satu atau lebih kelompok eksperimen tanpa melibatkan kelompok kontrol. Penelitian ini menggunakan teknik cluster random sampling, diambil 2 kelas dari kelas X SMA Negeri 1 Petanahan, Kebumen, masing masing kelas $\mathrm{X} 4$ berjumlah 32 dan kelas X7 berjumlah 31 siswa. Kedua kelas tersebut kemudian mendapatkan perlakuan yang berbeda. Kelas X4 pada eksperimen I diberikan pembelajaran dengan model pembelajaran STS menggunakan metode eksperimen lapangan sedangkan kelas $\mathrm{X} 7$ pada eksperimen II diberi pembelajaran dengan model STS dengan metode eksperimen laboratorium. Analisis penelitian ini menggunakan ANAVA 3 jalan dengan desain faktorial $2 \times 2 \times 2$.

Teknik pengumpulan data menggunakan metode tes untuk mendapatkan data prestasi belajar kognitif, psikomotor dan kreativitas verbal siswa, metode angket untuk mendapatkan data sikap peduli lingkungan, prestasi belajar afektif serta metode observasi untuk memperoleh data afektif dan psikomotorik selama proses pembelajaran

Pada penelitian ini menggunakan instrumen yaitu silabus, Rencana Pelaksanaan Pembelajaran (RPP), Lembar Kerja Siswa (LKS), Instrumen pengambilan data berupa soal tes, angket dan lembar observasi. Soal tes digunakan untuk memperoleh data prestasi belajar kognitif, psikomotor dan kreativas verbal, angket digunakan untuk memperoleh data sikap peduli lingkungan dan prestasi belajar afektif, dan lembar observasi digunakan untuk memperoleh data prestasi belajar afektif dan psikomotor selama pembelajaran. Validasi isi instrumen dilakukan oleh tim ahli sebelum diujicobakan. Try out dilaksanakan di SMA Negeri 1 Rowokele kelas X semester 1 Tahun Pelajaran 2012/2013. Selanjutnya sesudah uji coba, kemudian dilakukan analisis taraf kesukaran, daya beda, validitas dan reliabilitas soal-soal tes prestasi.

\section{Hasil Penelitian}

Data-data yang terkumpul pada penelitian ini meliputi: data prestasi belajar kognitif, prestasi belajar afektif, dan prestasi belajar psikomotorik. Data tersebut diperoleh dari hasil tes dan angket pada siswa kelas X4 dengan jumlah 32 siswa dan X7 dengan jumlah 31 siswa. Pada penelitian ini kelas $\mathrm{X} 4$ sebagai kelas yang diberikan perlakuan metode eksperimen lapangan dan kelas $\mathrm{X} 7$ sebagai kelas yang diberikan perlakuan metode eksperimen laboratorium.

\section{Data Prestasi Belajar Kognitif}

Deskripsi data prestasi belajar Kognitif disajikan pada Tabel 1.

Tabel 1: Data Prestasi Belajar Kognitif

\begin{tabular}{llll}
\cline { 2 - 3 } Metode & & Mean & SD \\
\hline \multirow{2}{*}{ Sikap Peduli Lingk } & Eks. Lap & 79,22 & 6,41 \\
\cline { 2 - 4 } & Eks Lab & 74,68 & 5,25 \\
\hline \multirow{2}{*}{ Kreativitas Verbal } & Tinggi & 79,00 & 6,37 \\
\cline { 2 - 4 } & Rendah & 74,90 & 5,04 \\
\cline { 2 - 4 } & Tinggi & 79,13 & 6,23 \\
\hline
\end{tabular}


ISSN: 2252-7893, Vol 2, No 32013 (hal 204-215)

\section{http://jurnal.fkip.uns.ac.id/index.php/sains}

Tabel 1 memperlihatkan siswa yang menggunakan model STS melalui eksperimen lapangan lebih baik dibanding siswa dengan model STS melalui eksperimen laboratorium. Siswa yang memiliki sikap peduli lingkungan dan kreativitas tinggi memperoleh nilai rata-rata lebih baik dari pada siswa yang memiliki sikap peduli lingkungan dan kreativitas verbal rendah.

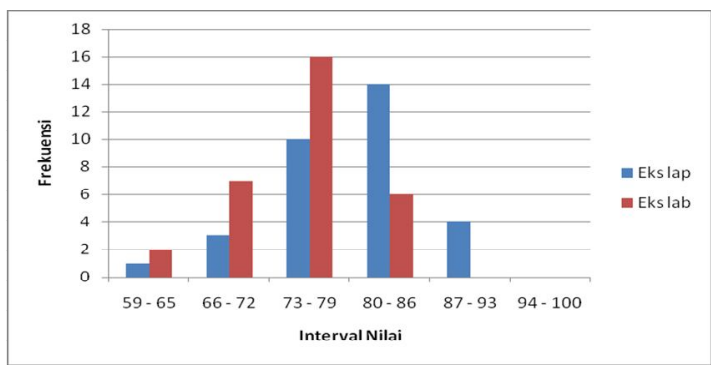

Gambar 1. Histogram Perbandingan Prestasi Kognitif Kelas Eksperimen Lapangan dan Eksperimen Laboratorium

\section{Data Prestasi Afektif}

Deskripsi data prestasi belajar afektif disajikan pada Tabel 2.

Tabel 2: Data Prestasi Belajar Afektif

\begin{tabular}{llll}
\cline { 2 - 3 } & & Mean & SD \\
\hline \multirow{2}{*}{ Metode } & Eks. Lap & 77,91 & 6,43 \\
\cline { 2 - 4 } & Eks Lab & 72,71 & 4,89 \\
\hline \multirow{2}{*}{ Sikap Peduli Lingk } & Tinggi & 77,72 & 6,44 \\
\cline { 2 - 4 } & Rendah & 72,94 & 5,07 \\
\hline \multirow{2}{*}{ Kreativitas Verbal } & Tinggi & 77,23 & 6,78 \\
\cline { 2 - 3 } & Rendah & 73,56 & 5,17 \\
\hline
\end{tabular}

Tabel 2 memperlihatkan siswa yang menggunakan model STS melalui eksperimen lapangan lebih baik dibanding siswa dengan model STS melalui eksperimen laboratorium. Siswa yang memiliki sikap peduli lingkungan dan kreativitas tinggi memperoleh nilai rata-rata lebih baik dari pada siswa yang memiliki sikap peduli lingkungan dan kreativitas verbal rendah.

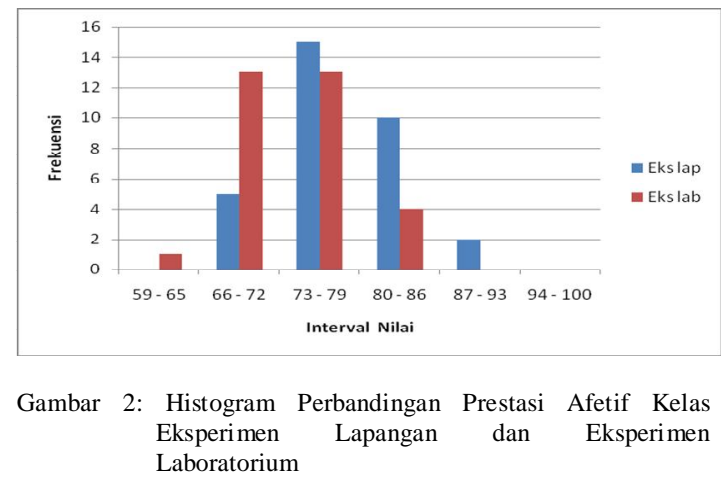

\section{Data Prestasi Psikomotor}

Deskripsi data prestasi belajar psikomotor disajikan pada Tabel 3.

Tabel 3: Data Prestasi Belajar Psikomotor

\begin{tabular}{llll}
\cline { 2 - 3 } & & Mean & SD \\
\hline \multirow{2}{*}{ Metode } & Eks. Lap & 83,47 & 6,68 \\
\cline { 2 - 4 } & Eks Lab & 78,65 & 5,61 \\
\hline \multirow{2}{*}{ Sikap Peduli Lingk } & Tinggi & 83,59 & 6,83 \\
\cline { 2 - 4 } & Rendah & 78,53 & 5,51 \\
\hline \multirow{2}{*}{ Kreativitas Verbal } & Tinggi & 83,74 & 6,44 \\
\cline { 2 - 4 } & Rendah & 78,53 & 5,93 \\
\hline
\end{tabular}

Tabel 3 memperlihatkan siswa yang menggunakan model STS melalui eksperimen lapangan lebih baik dibanding siswa dengan model STS melalui eksperimen laboratorium. Siswa yang memiliki sikap peduli lingkungan dan kreativitas tinggi memperoleh nilai rata-rata lebih baik dari pada siswa yang memiliki sikap peduli lingkungan dan kreativitas verbal rendah.

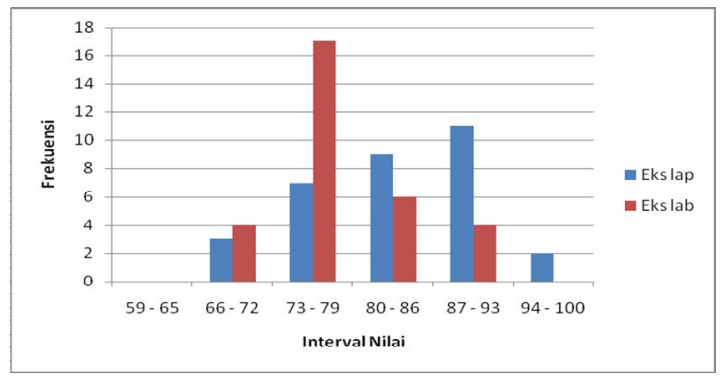

Gambar 3: Histogram Perbandingan Prestasi Psikomotor Kelas Eksperimen Lapangan dan Eksperimen Laboratorium

\section{Pengujian Persyaratan Analisis}

Berdasarkan hasil uji normalitas, didapat sig $>0,05$, sehingga disimpulkan semua data berdistribusi normal. Berdasarkan uji homogenitas diperoleh sig $>0,05$, sehingga $\mathrm{H}_{0}$ disimpulkan bahwa data mempunyai varian yang homogen.

Uji hipotesis dalam penelitian ini dilakukan dengan uji anava (analisis variansi) tiga jalan, karena faktor yang terlibat dan bertindak sebagai variabel bebas berjumlah tiga variabel bebas, yaitu metode pembelajaran, sikap peduli lingkungan, dan kreativitas verbal, menggunakan program SPSS 18. Adapun ringkasan hasil analisis variansi tiga jalan diperlihatkan dalam Tabel 4 berikut.

Tabel 4. Hasil Uji Hipotesis Anava Tiga Jalan Prestasi Kognitif, Afektif dan Psikomotorik 
ISSN: 2252-7893, Vol 2, No 32013 (hal 204-215)

http://jurnal.fkip.uns.ac.id/index.php/sains

\begin{tabular}{|c|c|c|c|c|}
\hline \multirow[b]{2}{*}{ NO } & \multirow[b]{2}{*}{ SOURCE } & \multicolumn{3}{|c|}{ P-value } \\
\hline & & $\begin{array}{l}\text { Prest. } \\
\text { Kognitif }\end{array}$ & $\begin{array}{l}\text { Prest. } \\
\text { Afektif }\end{array}$ & $\begin{array}{l}\text { Prest. } \\
\text { Psikomotorik }\end{array}$ \\
\hline 1 & Eksperimen & 0,012 & 0,003 & 0,014 \\
\hline 2 & $\begin{array}{l}\text { Sikap Peduli } \\
\text { Lingkungn }\end{array}$ & 0,034 & 0,009 & 0,007 \\
\hline 3 & Kreativitas verbal & 0,012 & 0,035 & 0,002 \\
\hline 4 & $\begin{array}{l}\text { Eksperimen * } \\
\text { Sikap Peduli } \\
\text { Lingkungan }\end{array}$ & 0,022 & 0,034 & 0,042 \\
\hline 5 & $\begin{array}{l}\text { Eksperimen * } \\
\text { Kreativitas verbal }\end{array}$ & 0,392 & 0,601 & 0,341 \\
\hline 6 & $\begin{array}{l}\text { Sika Peduli } \\
\text { Lingkungan * } \\
\text { Kreativitas verbal } \\
\text { Eksperimen * }\end{array}$ & 0,043 & 0,048 & 0,031 \\
\hline 7 & $\begin{array}{l}\text { Sikap Peduli } \\
\text { Lingkungan* } \\
\text { Kreativitas verbal }\end{array}$ & 0,432 & 0,451 & 0,388 \\
\hline
\end{tabular}

\section{Pembahasan}

\section{Pengaruh Model STS Melalui Eksperimen Lapangan dan Eksperimen Laboratorium Terhadap Prestasi Belajar}

Berdasarkan hasil analisis dapat diambil keputusan bahwa kedua metode baik eksperimen lapangan dan laboratorium memberikan perbedaan yang signifikan terhadap prestasi kognitif, afektif maupun psikomotorik siswa. Artinya STS yang diintegrasikan dengan metode eksperimen lapangan dan laboratorium memberikan dampak yang berbeda terhadap prestasi belajar kognitif, afektif dan psikomotorik siswa. Hasil prestasi kognitif, afekif dan psikomotorik dari penggunaan metode eksperimen lapangan dan laboratorium berbeda.

Menurut Nuray Yoruk et al (2010), pembelajaran dengan STSE menunjukan hasil prestasi lebih baik dibandingkan dengan pembelajaran konvensional. Hal ini disebabkan karena pembelajaran dengan STSE mengangkat topik permasalahan yang ada di lingkungan sehingga siswa mudah memahami topik dan konsep-konsep permasalahan. Hal ini sesuai dengan teori belajar pragmatisme. Menurut Pudjiadi (2005) pragmatisme berpandangan bahwa pengetahuan yang diperoleh hendaknya dimanfaatkan untuk mengerti permasalahan yang ada di masyarakat. Selanjutnya tindakan apa yang dapat dilakukan untuk kebaikan, peningkatan dan kemajuan masyarakat dan dunia. Gagasan, ide-ide dan teori, yang dipentingkan adalah dapat atau tidaknya gagasan itu dilaksanakan hingga membuahkan hasil positif. Kaum pragmatis memandang bahwa teori-teori itu diperlukan untuk membimbing tingkah laku manusia dan perencanaan untuk melakukan tindakan hingga berdampak positif menghasilkan kemajuan dan bermanfaat bagi kehidupan manusia.

Di samping itu juga pembelajaran dengan STSE menuntut siswa lebih aktif selama pembelajaran atau pembelajaran bersifat student center terutama dalam memahami, menemukan konsep limbah organik dan anorganik hingga menemukan ide memecahkan masalah limbah organik yang ada di masyarakat sehingga siswa lebih aktif dalam pembelajaran. Hal ini sesuai dengan teori belajar konstruktivisme. Menurut Nur (2002) pembelajaran menggunakan pendekatan konstruktivisme memiliki ciri-ciri sebagai berikut: (1) siswa lebih aktif dalam pembelajaran karena fokus belajar siswa pada proses integrasi pengetahuan yang baru dengan pengalaman pengetahuan mereka yang telah dimiliki; (2) setiap pendapat yang berbeda akan dihargai dan diperlukan, siswa didorong untuk menemukan kemungkinan dan mensintesiskan secara integrasi; (3) proses pembelajaran mendorong adanya kerjasama, tetapi bukan untuk bersaing. Proses belajar melalui kerjasama memungkinkan siswa untuk mengingat pelajaran lebih lama; (4) kontrol kecepatan dan fokus pelajaran pada siswa. Cara ini dipandang lebih memberdayakan siswa; (5) pendekatan konstruktivisme memberikan pengalaman belajar yang tidak terlepas dari konteks dunia nyata.

Pembelajaran model STS merupakan suatu strategi pembelajaran yang memadukan pemahaman dan pemanfaatan sains, teknologi dan masyarakat dengan tujuan agar konsep sains dapat diaplikasikan melalui keterampilan yang bermanfaat bagi peserta didik dan masyarakat. Metode eksperimen merupakan cara penyajian materi dengaan menggunakan percobaan. Lebih luas lagi disampaikan oleh Udin S. Winataputra (1994:219) bahwa metode eksperimen adalah suatu cara penyajian materi pelajaran dimana siswa secara aktif mengalami dan membuktikan sendiri tentang yang dipelajarinya. Hal ini selaras dengan yang dikemukakan Wina Sanjaya (2008:152) metode eksperimen dapat dikatakan metode yang ideal, karena siswa pada umumnya menemukan dan memahami konsep melalui pengalaman sendiri. Pembelajaran menggunakan metode eksperimen dengan harapan siswa memiliki 
ISSN: 2252-7893, Vol 2, No 32013 (hal 204-215)

http://jurnal.fkip.uns.ac.id/index.php/sains

kesempatan mengalami sendiri, mengikuti proses, mengukur, mengamati, menganalisis, membuktikan konsep dan menarik kesimpulan. Hal ini sesuai dengan terori belajar penemuan Bruner. Menurut Bruner (dalam Herawati, 2003:33) "pada proses belajar penemuan, siswa didorong oleh rasa ingin tahu untuk mengeksplorasi dan belajar sendiri". Rasa ingin tahu menjadikan peserta didik berada pada masalah atau situasi yang membingungkan. Melalui pengalaman yang dimiliki, siswa mencoba untuk memecahkan masalah tersebut dan menemukan pengetahuan yang baru. Bruner menganggap bahwa belajar penemuan sesuai dengan pencarian pengetahuan secara aktif oleh manusia, dan dengan sendirinya memberikan hasil yang paling baik. Belajar mencari dengan sendiri pemecahan dari masalah akan menghasilkan pengetahuan yang bermakna. Hal ini sesuai dengan belajar bermakna yang dikemukakan David Ausubel. Menurut Ausubel (dalam Dahar, 2006) belajar bermakna hanya terjadi bila siswa menemukan sendiri pengetahuan. Eksperimen dalam model STS adalah melakukan percobaan untuk memecahkan permasalahan yang ada dilingkungan dan bukan membuktikan atau menemukan suatu konsep tertentu.

\section{Pengaruh Sikap Peduli Lingkungan Tinggi dan Rendah Terhadap Prestasi Belajar}

Dengan pembelajaran yang dilakukan dengan model STS diharapkan siswa mendapat pengalaman dalam mendapatkan masalah sampai dengan menangani dan memecahkan masalah di masyarakat pembelajaran lebih bermakna. Siswa akan dapat menentukan sikap terhadap lingkungan sebagai sumber belajar. Saifudin (2011) menjelaskan bahwa sikap kesiapan untuk bereaksi terhadap objek di lingkungan tertentu sebagai suatu penghayatan terhadap objek tersebut. Sikap berarti predisposison atau tendensi yaitu suatu kecendrungan, kesediaan dapat diramalkan tingkah laku apa yang terjadi jika telah diketahui sikapnya. Sikap belum merupakan suatu tindakan akan tetapi berupa pre-disposisi tingkah laku. Jika sikap mengarah pada obyek tertentu berarti penyesuaian diri terhadap objek tersebut dipengaruhi oleh lingkungan sosial dan kesediaan untuk bereaksi dari orang tersebut terhadap objek. Hal ini sesuai dengan teori belajar konstruktivisme Vygotsky yang dijelaskan oleh Trianto (2010 : 52) menyatakan bahwa proses belajar adalah suatu proses psikososial yang berkaitan dengan lingkungan sosial budayanya. Siswa mendapatkan stimulus dari lingkungan sekitarnya menggunakan fisiknya, untuk menyerap stimulus tersebut dengan inderanya sehingga berkembang ketika berinteraksi dengan lingkungannya. Menurut teori ini adanya kesadaran merupakan akhir dari interaksi sehingga menjadi pengetahuan yang personal (private speech). Siswa sering menggunakan pengetahuan ini misalnya saat mengerjakan masalah yang sulit dengan berbicara sendiri. Sejalan dengan hal ini, Saifudin (2011:5) sikap merupakan konstelasi komponen-komponen kognitif, afektif dan konatif yang saling berinteraksi terhadap suatu objek, sementara Kothandapani dan Mann (dalam Saifudin, 2011:24) menjelaskan komponen kognitif merupakan representasi apa yang dipercayai oleh individu pemilik sikap, komponen afektif merupakan perasaan yang menyangkut emosional dan konatif merupakan kecenderungan berperilaku terentu sesuai dengan sikap yang dimiliki oleh seseorang. Komponen kognitif berisi persepsi, kepercayaan stereotif yang dimiliki indivdu mengenai sesuatu. Sering kali komponen kognitif disamakan dengan pandangan (opini), terutama apabila menyangkut masalah issu atau masalah yang controversial. Komponen afektif merupakan perasaan individu terhadap objek sikap dan menyangkut masalah emosi. komponen perilaku berisi tendensi atau kecenderungan untuk bertindak atau untuk bereaksi terhadap sesuatu.

Dengan demikian dapat disimpulkan bahwa sikap peduli lingkungan berpengaruh secara signifikan terhadap prestasi belajar kognitif, afektif dan psikomotor sedangkan menurut Priadi (2012) ada pengaruh keberagaman sikap peduli lingkungan terhadap prestasi belajar kognitif dan psikomotor, prestasi belajar afektif tidak dan Restanti (2012) ada pengaruh keberagaman sikap peduli lingkungan terhadap prestasi belajar kognitif, afektif dan psikomotor.

\section{Pengaruh Kreativitas Verbal Tinggi dan Rendah Terhadap Prestasi Belajar}


ISSN: 2252-7893, Vol 2, No 32013 (hal 204-215)

\section{http://jurnal.fkip.uns.ac.id/index.php/sains}

Rerata prestasi belajar kognitif, afektif dan psikomotorik siswa yang yang memiliki keativitas verbal lebih tinggi dibandingkan siswa yang memiliki kreativitas verbal rendah. Hal ini berarti semakin tinggi krativitas verbal siswa maka akan semakin baik prestasi belajar yang diperoleh.

Munandar (2009) mengatakan bahwa salah satu faktor untuk menentukan keberbakatan seseorang adalah kreativitas untuk berprestasi. Kreativitas atau daya cipta memungkinkan penemuan-penemuan baru dalam bidang ilmu dan teknologi serta dalam semua bidang usaha maupun lainnya. Hal ini sesuai dengan teori belajar menurut Bruner (dalam Dahar, 1988: 103) menyatakan "belajar penemuan sesuai pencarian pengetahuan secara aktif oleh manusia dan dengan sendirinya memberikan hasil yang paling baik". Siswa aktif mencari pemecahan masalah serta pengetahuan yang menyertainya akan menghasilkan pengetahuan yang benar-benar bermakna. Hal ini juga sejalan dengan penelitian oleh Restanti (2012), menyimpulkan bahwa kreativitas yang berkembang dapat meningkatkan hasil prestasi belajar siswa. Kreativitas melibatkan belajar memecahkan masalah dan memerlukan banyak latihan dengan berbagai macam tipe masalah serta membutuhkan pemikirn yang kritis, realistis yang bersifat sontan atau imrofisasi. Semakin banyak masalah yang dipelajari siswa untuk dipecahkan maka semakin banyak siswa tersebut berfikir sehingga kemampuan kognitif, afektif dan psikomotor semakin meningkat.

\section{Interaksi Penggunaan Metode Eksperimen Lapangan dan Eksperimen Laboratorium dengan Sikap Peduli Lingkungan Terhadap Prestasi Belajar}

Interaksi antara metode dan sikap peduli lingkungan ini terjadi karena prestasi belajar pada hakekatnya dipengaruhi oleh faktor internal ataupun eksternal yang beragam. Jean Piaget dalam teori perkembangannya mengungkapkan bahwa perkembangan seseorang sebagian bergantung pada seberapa jauh anak aktif memanipulasi dan berinteraksi aktif dengan lingkungan. Lingkungan dimana anak belajar sangat menentukan prestasi anak. Hal ini mengindikasikan bahwa sikap terhadap lingkungan memiliki peranan penting tehadap prestasi anak. Hal ini sejalan dengan pendapat
Saifudin ( 2011 : 11) yang menjelaskan bahwa karakteristik individu meliputi berbagai variabel seperti motif, sifat-sifat kepribadian dan sikap yang saling berinteraksi satu sama lain dan kemudian berinteraksi pula dengaan faktor-faktor lingkungan dalam menentukan perilaku. Perilaku secara luas tentu tidak hanya dapat ditinjau dalam kaitannya dengan dengan sikap manusia. Pembahasan perilaku dari sudut motivasi, dari sisi teori belajar dan sudut pandang lain akan memberikan penekanan yang berbeda. Namun satu hal yang dapat disimpulkan bahwa perilaku manusia tidaklah sederhana untuk dipahami dan diprediksikan. Begitu banyak faktor-faktor internal dan eksternal dari dimensi masa lalu, saat ini dan masa mendatang yang ikut mempengaruhi perilaku manusia. Selain berbagai faktor penting seperti hakikat stimulus itu sendiri, latar belakang pengalaman individu, motivasi, status kepribadian ikut memegang peranan penting dalam menentukan bagaimanakah perilaku seseorang terhadap lingkungannya. Pada gilirannya, lingkungan secara timbal balik akan mempengaruhi sikap dan perilaku. Interaksi antara situasi lingkungan dengan sikap serta berbagai faktor dalam maupun luar diri individu akan membentuk suatu proses kompleks yang akhirnya menentukan bentuk perilaku seseorang.

Sikap terbentuk dan berubah sejalan dengan perkembangan individu atau dengan kata lain sikap merupakan hasil belajar individu melalui interaksi sosial. Hal ini berarti bahwa sikap dapat dibentuk dan diubah melalui pendidikan. Sikap positif dapat berubah menjadi negatif jika tidak mendapat pembinaan dan sebaliknya sikap negatif dapat berubah menjadi positif jika mendapatkan pembinaan yang baik. Karena sikap mempunyai valensi / tingkatan maka sikap positif dapat juga ditingkatkan menjadi sangat positif. Di sinilah letak peranan pendidikan dalam membina sikap siswa (Suparno, 2001).

\begin{tabular}{llll} 
Interaksi Metode Eksperimen Lapangan dan \\
Eksperimen & \multicolumn{2}{c}{ Laboratorium } & Dengan \\
Kreativitas & Verbal & Terhadap & Prestasi
\end{tabular} 
ISSN: 2252-7893, Vol 2, No 32013 (hal 204-215)

http://jurnal.fkip.uns.ac.id/index.php/sains

\section{Belajar}

Tidak adanya interaksi antara metode pembelajaran tersebut dengan kreativitas terhadap hasil prestasi belajar siswa dapat dipahami karena kreativitas merupakan bakat yang secara potensial dimiliki oleh setiap orang, yang dapat ditemukenali (diidentifikasi) dan dipupuk melalui pendidikan. Kemampuan kreativitas merupakan faktor genetis yang telah menyatu dengan seseorang yang selalu mendominasi dan berpengaruh langsung dalam semua aspek kehidupannya termasuk dalam proses belajar. Kemampuan kreativitas seseorang 2/3 diperoleh melalui pendidikan dan $1 / 3$ sisanya berasal dari genetik. Kemampuan kreativitas diperoleh melalui: observing (mengamati), questioning (bertanya), associating (menalar), experimenting (mencoba) dan networking (membentuk jaringan/kelompok) (Dyers et al, 2011). Menurut Munandar (2009), perkembangan optimal berfikir kreatif berhubungan erat dengan cara mengajar. Dalam suasana nonotoriter, ketika belajar atas prakarsa sendiri dapat berkembang, karena guru menaruh kepercayaan terhadap kemampuan anak untuk berfikir dan berani mengemukakan gagasan baru dan ketika anak diberi kesempatan untuk bekerja sesuai dengan minat dan kebutuhannya, dalam suasana inilah kemampuan kreatif dapat tumbuh dengan subur. Tidak adanya interaksi antara metode baik eksperimen lapangan maupun laboratorium dengan kreativitas mungkin disebabkan karena waktu yang kurang dalam pembelajaran. Dalam pembelajaran STS dengan eksperimen lapangan dan eksperimen laboratorium anak dituntut harus segera menyelesaikan kegiatan pembelajaran karena waktunya terbatas, sehingga siswa tidak diberi kesempatan untuk bekerja sesuai dengan minat dan kebutuhannya sebagai simulus untuk menumbuhkan kemampuan kreatif. Menurut Porter dan Hernacki (2001:301) dalam bukunya Quantum Learning bahwa kreativitas mengalir melalui lima tahap, tahap-tahap tersebut sebagai berkut: 1) persiapan: mendifinisikan masalah, tujuan atau tantangan; 2) inkubasi: mencerna fakta-fakta dan mengolahnya dalam pikiran; 3) iluminasi: mendesak ke permukaan, gagasagagasan bermunculan; 4) verifikasi: memastikan apakah solusi yang diusulkan benar-benar memecahkan masalah; 5) aplikasi: mengambil langkah-langkah untuk menindak lanjuti solusi tersebut. Dengan demikian siswa harus menyesuaikan dengan kemampuan dan potensi yang ada sebagai faktor potensi pribadi sehingga secara umum dapat dinyatakan tidak ada interaksi antara penerapan model STS dengan eksperimen lapangan dan eksperimen laboratorium dengan kreativitas siswa. Namun demikian prestasi belajar biologi siswa dengan kreativitas tinggi yang menggunakan eksperimen lapangan dan eksperimen laboratorium tetap lebih baik dari prestasi belajar biologi siswa dengan kreativitas rendah.

\section{Interaksi Antara Sikap Peduli Lingkungan Dengan Kreativitas Verbal Siswa Terhadap Prestasi Belajar}

Selama mempelajari biologi khususnya materi limbah dan upaya mengatasinya, agar menghasilkan pemahaman secara menyeluruh, diperlukan adanya kemampuan kreativitas yang tinggi serta suatu sikap peduli lingkungan yang tinggi pula karena dalam mempelajari biologi khususnya materi limbah dan upaya mengatasinya diperlukan kedua hal tersebut. Menurut Ausubel (dalam Dahar, 2006)" belajar bermakna merupakan suatu proses mengaitkan informasi baru pada konsep-konsep relevan yang terdapat dalam struktur kognitif seseorang". Agar individu dapat mengaitkan informasi baru dalam pembelajaran diperlukan suatu kreativitas siswa. Menurut Torrance (dalam Munandar, 2009), kreativitas merupakan bakat yang secara potensial dimiliki oleh setiap orang, yang dapat ditemukenali (diidentifikasi) dan dipupuk melalui pendidikan.

Sikap mempunyai tiga komponen yaitu kognitif yang berhubungan dengan pengetahuan, afektif yang berhubungan dengan perasaan dan psikomotoris yang berhubungan dengan kecenderungan untuk bertindak. Struktur kognitif merupakan pangkal terbentuknya sikap seseorang. Struktur kognitif ini sangat ditentukan oleh pengetahuan atau informasi yang berhubungan dengan sikap, yang diterima seseorang (Suparno, 2001).

Sikap terbentuk dan berubah sejalan dengan perkembangan individu atau dengan kata lain sikap merupakan hasil belajar individu melalui interaksi sosial. Hal ini berarti bahwa sikap dapat dibentuk dan diubah melalui pendidikan. Sikap positif dapat berubah menjadi negatif jika tidak mendapat pembinaan dan sebaliknya sikap negatif dapat berubah menjadi positif jika mendapatkan pembinaan 
ISSN: 2252-7893, Vol 2, No 32013 (hal 204-215)

\section{http://jurnal.fkip.uns.ac.id/index.php/sains}

yang baik. Karena sikap mempunyai valensi/tingkatan maka sikap positif dapat juga ditingkatkan menjadi sangat positif. Di sinilah letak peranan pendidikan dalam membina sikap siswa (Suparno, 2001). Sikap peduli lingkungan yang tinggi ditambah dengan kreativitas siswa yang tinggi dapat meningkatkan prestasi belajar siswa.

Prestasi belajar ditentukan oleh kualitas proses pembelajaran. Pembelajaran ditentukan oleh karakteristik masukannya/input siswa, yaitu karakteristik siswanya. Karakteristik siswa yang kreatif merupakan modal dari prestasi belajar dan memiliki peranan penting dalam keberhasilan pembelajaran pada ranah kognitif, afektif dan psikomotor.

Interaksi Penggunaan Metode Eksperimen Lapangan dan Eksperimen Laboratorium, Sikap Peduli Lingkungan Dengan Krativitas Verbal Siswa Terhadap Prestasi Belajar

Interaksi penggunaan metode ekdperimen lapangan dan eksperimen laboratorium, sikap peduli lingkungan dengan kerativitas verbal siswa terhadap prestasi belajar kognitif, afektif dan psikomotorik; pada tabel Anava Test, prestasi kognitif, afektif dan psikomotorik siswa sama-sama menunjukkan tidak ada perbedaan yang signifikan pada kedua metode pembelajaran yang diterapkan, ditunjukkan dengan nilai signifikansi masing-masing 0,432 , 0,451 dan 0,388 (sig< 5\%; Ho ditolak). Artinya rerata prestasi kognitif, afektif dan psikomotorik tidak berbeda pada kedua metode yang diterapkan.

Berdasarkan hasil analisis di atas dapat dijelaskan bahwa model STS dengan eksperimen lapangan dan eksperimen labortorium yang diinteraksikan dengan sikap peduli lingkungan dan kreativitas menjadikan hasil belajar yang diperoleh dari kedua kelompok penelitian tidak berbeda. Tidak adanya perbedaan yang signifikan menunjukkan bahwa ketiga variabel yang diinteraksikan saling independen. Hasil yang diperoleh dari penelitian ini adalah tidak ada interaksi antara antara model pembelajaran STS dengan eksperimen lapangan dan eksperimen labortaorium dengan sikap peduli lingkungan dan kreativitas siswa terhadap prestasi belajar kognitif, afektif, dan psikomotor. Namun demikian perlu diingat bahwa prestasi belajar yang diraih oleh siswa tidak semata-mata karena pengaruh model pembelajaran yang digunakan, tetapi juga dipengaruhi oleh proses persiapan model pembelajaran untuk digunakan, kelancaran proses pelaksanaan, dan berfungsinya daya dukung yang lain.

Adapun ilustrasi pemodelan hasil hipotesis secara keseluruhan disajikan pada Gambar 4.

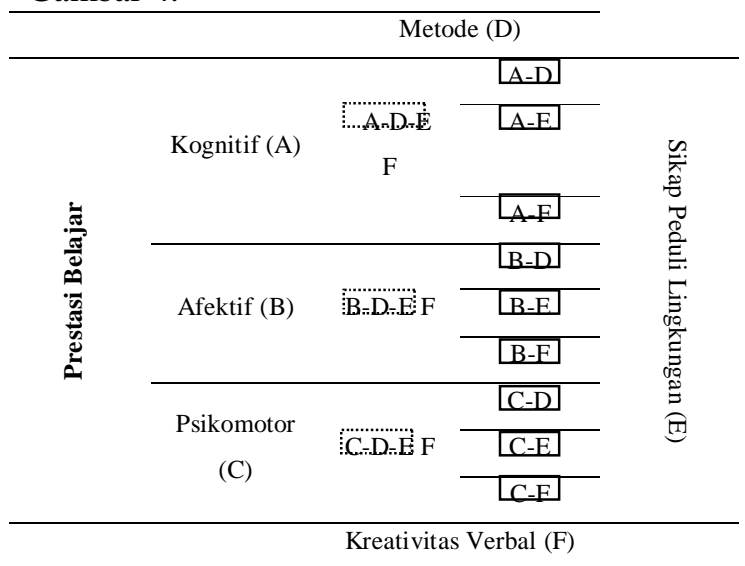

Gambar 4: Ilustrasi Pemodelan Hasil Uji Hipotesis

Keterangan: $\square$ : ada pengaruh

Berdasarkan Gambar 4. diketahui bahwa ada pengaruh antara metode, keberagaman sikap peduli lingkungan dan kreativitas verbal terhadap prestasi belajar kognitif, afektif dan psikomotor, ada interaksi antara metode dengan keberagaman sikap peduli lingkungan terhadap prestasi belajar kognitif, afektif dan psikomotor, serta tidak ada interaksi antara metode dengan keberagaman kreativitas verbal terhadap prestasi belajar kognitif, afektif da psikomotor. Berdasarkan data tersebut jika ada pengaruh antara prestasi kognitif (A) dengan variabel yang lain akan dapat menyebabkan terjadinya interaksi seluruh variabel. Artinya prestasi kognitif memiliki pengaruh yang kuat untuk terjadinya interaksi antar variabel. Ini bisa menjadi salah satu alasan mengapa para guru cenderung menggunakan penilaian kognitif untuk mengukur prestasi belajar siswa.

\section{Kesimpulan dan Rekomendasi}


ISSN: 2252-7893, Vol 2, No 32013 (hal 204-215)

\section{http://jurnal.fkip.uns.ac.id/index.php/sains}

Berdasarkan hasil analisis data dan pembahasan sebelumnya, penelitian ini menghasilkan beberapa kesimpulan sebagai berikut: 1) ada pengaruh pembelajaran model STS melalui metode eksperimen lapangan dan laboratorium terhadap prestasi kognitif, afektif, psikomotor belajar siswa pada pembelajan biologi materi limbah dan upaya mengatasinya siswa kelas X SMA Negeri 1 Petanahan Tahun Pelajaran 2012/2013; 2) ada pengaruh keberagaman sikap peduli lingkungan terhadap prestasi belajar kognitif, afektif dan psikomotor siswa pada pembelajan biologi materi limbah dan upaya mengatasinya siswa kelas X SMA Negeri 1 Petanahan Tahun Pelajaran 2012/2013; 3) ada pengaruh keberagaman kreativitas verbal terhadap prestasi kognitif, afektif, psikomotor belajar siswa pada pembelajan biologi materi limbah dan upaya mengatasinya siswa kelas X SMA Negeri 1 Petanahan Tahun Pelajaran 2012/2013; 4) Ada interaksi antara model STS melalui metode eksperimen lapangan dan laboratorium dengan keberagaman sikap peduli lingkungan terhadap prestasi kognitif, afektif, psikomotor belajar siswa pada pembelajan biologi materi limbah dan upaya mengatasinya siswa kelas X SMA Negeri 1 Petanahan Tahun Pelajaran 2012/2013; 5) tidak ada interaksi antara model STS melalui metode eksperimen lapangan dan laboratorium dengan keberagaman kreativias verbal terhadap prestasi kognitif, afektif, psikomotor belajar siswa pada pembelajan biologi materi limbah dan upaya mengatasinya siswa kelas X SMA Negeri 1 Petanahan Tahun Pelajaran 2012/2013; 6) ada interaksi antara keberagaman sikap peduli lingkungan dengan kreativitas verbal terhadap prestasi kognitif, afektif, psikomotor belajar siswa pada pembelajan biologi materi limbah dan upaya mengatasinya siswa kelas X SMA Negeri 1 Petanahan Tahun Pelajaran 2012/2013; 7) tidak ada interaksi antara model STS melalui metode eksperimen lapangan dan laboratorium, keberagaman sikap peduli lingkungan, dengan kreativitas verbal terhadap prestasi belajar kognitif, afektif dan psikomotorik siswa pada pembelajan biologi materi limbah dan upaya mengatasinya siswa kelas X SMA Negeri 1 Petanahan Tahun Pelajaran 2012/2013.

Rekomendasi bagi guru agar guru Biologi menggunakan model STS dengan eksperimen lapangan dan eksperimen laboratorium pada materi limbah dan upaya mengatasinya dalam kegiatan pembelajaran di sekolah dan memperhatikan waktu pembelajaran agar dapat berjalan efektif dan baik. Bagi sekolah supaya mengembangkan dan menggunakan model dan metode pembelajaran yang menarik dan dapat meningkatkan prestasi siswa untuk meningkatkan mutu pendidikan sekolah khususnya mata pelajaran Biologi dengan menggunakan model STS dan metode eksperimen lapangan serta menyediakan peralatan yang memadai untuk mendukung pembelajaran. Bagi peneliti lain dalam penelitian ini yaitu: 1) hasil penelitian ini hanya pada peserta didik SMA Negeri 1 Petanahan, sehingga perlu dilakukan penelitian di sekolah yang lain dengan kategori rendah dan tinggi untuk memperoleh temuan yang lebih bervariasi; 2) mempertimbangkan ketersediaan alat-alat praktikum yang di laboratorium sekolah sejak awal agar waktu dan pelaksanaan penelitian dapat berjalan secara efektif dan efisien; 3) pengambilan data sikap peduli lingkungan akan lebih representatif jika menggunakan angket dan observasi serta mempertimbangkan keterbatasan waktu.

\section{DAFTAR PUSTAKA}

Ana Poedjiadi. (2005). Sains Teknologi Masyarakat. Model pembelajaran Kontekstual Bermuatan Nilai. Bandung: Remaja Rosdakarya.

BSNP.(2008). Kerangka Dasar Pengembangan Kurikulum dan Standar Isi. Jakarta: Ditjen PMPTK.

Dahar, R.W.(2006). Teori-teori Belajar dan Pembelajaran. Jakarta: Erlangga.

Daniel Fasko, Jr.2001. Education and Creativity. Vol 13, No 3\&4, 317-327. Creativity Research Journal.

Ditjen PMPTK.(2007). Tantangan Kebijakan, dan Program Strategi Peningkatan Mutu Pendidik dan Tenaga Kependidikan. Makalah rembug Nasional. Jakarta: Ditjen PMPTK, Depdiknas.

Dyer, J.H, Hal B. Gregersen, Clayton M. Christensen. 2011. The Innovator's DNA: Mastering The Five Skill of Disruptive Innovators. New York. Havard Business Press Book.

Elif Bakar, Senol Bal, Hakam Akcay. (2006). Preservice science teacher beliefs about science-technology and their implication in society. Eurasia Journal of Mathematics, Science and Technology Education. Vol.2, No.3. Diunduh dari http://www.ejmste.com 
http://jurnal.fkip.uns.ac.id/index.php/sains

Fatih Aydin, Mehmet Fatih Tasar. 2008. Development of Pre-service Science Teacher View about Nature of Technology and Effectivenss of Dilemmas in Teaching. Eurasia Journal of Mathematics, Science and Technology Education. Vol.6, No.5. Diunduh dari http://www.ejmste.com

Hassan H. Tairab.(2001). How do pre-service and in-service science teacher view the natureof science and technology. Vol.19, No.2. Reserch in Science and Technology Education Journal.

Herawati Susilo.(2003).Kapita Selekta Pembelajaran Biologi. Jakarta: Universitas Terbuka.

Ijas Ahmad Tatlah, Tahzeen Mehmood Aslam, Zulfikar Ali, Muhammad Iqbal. 2012. Role of Intelligence and Creativity In The Academic Achievement of Students. Vol 2, No 7. International Journal of Physical and Social Science.

Judith Bennett, Fred Lubben, Sylvia Hogarth. (2006). Bringing science to life: A synthesis of the research evidence on the effects of context based and STS approaches to science teaching. Department of Education Studies, University of York. www.interscience.wiley.com

Median Agus Priadi. (2012). Pembelajaran Biologi Menggunakan Model Problem Based Learning Melalui Metode Eksperimen Labortaorium dan Lapangan Ditinjau dari Keberagaman Kemampuan Berfikir Analitis dan Sikap Peduli Lingkungan. Tesis Program Pascasarjana. UNS.

Muhamad Nur. (2000). Pengajaran Berpusat Pada Siswa dan Pendekatan Konstruktivisme dalam Pengajaran. Surabaya: University Press.

Munir Tanrere. (2008). Environmental problem solving in learning chemistry for high school students. Chemistry departement. Faculty of mathematics and Natural Science, Makasar state University. http://www.trisnita.org

Nuray Yoruk, Inci Morgil, Nilgun Secken. (2010). The effects of science, technology,society, environment (STSE) interaction on teaching chemistry. Hacettepe University, chemistry Education, Ankara, Turkey. http://www.scrirp.org/journal/NS/

Porter, B D and Hernacki. (2001). Quantum Learning. Bandung. Penerbit Kaifa.

Rina Restanti.(2012).Pembelajaran Biologi Dengan Pendekatan CTL Melalui Model Formal dan Informal Hands On Activities Ditinjau dari Kreativitas Siswa dan Sikap Peduli Lingkungan. Tesis. UNS

Saifudin.(2011). Konsep dan Makna Pembelajaran. Bandung: Alfabeta.
Suciati Sudarisman. (2010). Membangun Karakter Peserta Didik Melalui Pembelajaran Biologi Berbasis Keterampilan Proses. Proceding Seminar Nasional VII Pendidikan Biologi FKIP UNS.

Suparno, A, S. (2001). Membangun Kompetensi Belajar. Departemen Pendidikan Nasional. Jakarta

Trianto.(2010).Model-Model Pembelajaran Tematik. Jakarta: Prestasi Pustaka Publisher.

Udin S. Winataputra.(2006).Pembelajaran yang Mendidik dan Dialogis Tinjauan Psikologis (Bahan Diskusi dan Latihan Diklat dalam Diklat Pedagogig Widya Wiwaha LPMP dan $P L P G)$. Jakarta: UT

Utami Munandar.(2009). Pengembangan Kreativitas Anak Berbakat. Jakarta: Rineka Cipta.

Wina Sanjaya.(2006). Strategi Pembelajaran Berorientasi Standar Proses Pendidikan. Jakarta: Kencana Prenanda Media Group.

Yager, Robert E.(1990). The Science Technology Society Movemen in the United States, Its Origin, Evolution, and Rationale, Social Education. 